\title{
On the Phylogeny of the Stele
}

\author{
by W. Zimmermann*
}

Received June 29, 1956

\section{Methods}

Our aim is to demonstrate the actual evolution of the stele. We wish to exhibit the phylogenetic process of life as it really took place in bygone time (viz. the historical process in the past and not an abstract performance in our mind). We thus search for the ancestral stages, for instance of the first steles in early land plants, and on the other hand for the events that lead from those early stages to the recent types of the stele.

There is a vast divergence of views about the phylogeny of the stele, caused by differences in methods. It results mainly from the varying interpretation of the word phylogeny that should be applied only to the actual, "real" (naturwirklichen) evolution prccess and not to an only intellectual linkage of the organisms. Up till now, for historical reasons, the notion phylogeny or evolution is often used in confusion or combination of the natural process with the human mental process. But in an exact methodology the word phylogeny should not be employed for speculative deduction ${ }^{1)}$ of a recent organ or organism from another recent organ or organism nor for derivation of ontogenetically "complete" steles from each other. Both these deductions contain partially right perceptions though mixed up with wrong conclusions.

For instance, a recent organism may represent some primitive features; but this does not justify to infer further: it is to be regarded as primitive in general, and it would be false to derive from such an organism any phylogenetically earlier organisms.

Equally, a series of ontogenetically "complete" steles may serve to exhibit the general course of phylogeny. But such isolated stages can not manifest the living

* Inst. f. Angewandte Botanik, Universität Tübingen, Deutschland.

1) There exists but a single natural connexion between different organisms which is represented by the phylogeny. Thus, when inferring different organisms from each other we have to describe either this phylogeny as the only connexion given by nature or to restrict to merely speculative correlations born from our mind. As a matte $r$ of course for every clean method it should be stated clearly, whether one is speaking of the natural process (the phylogeny) or an intellectual conception (a non-phylogenetical development). Phylogenetical conclusions are, as universally in natural science, conclusions of probabilities: we have to counterbalance the various possibilities and to decide for the most conclusive one. In most of the following questions this decision is eased by an evident probability. Not to accept such a conclusion as justified means to value the contradictory opposite as better founded. 


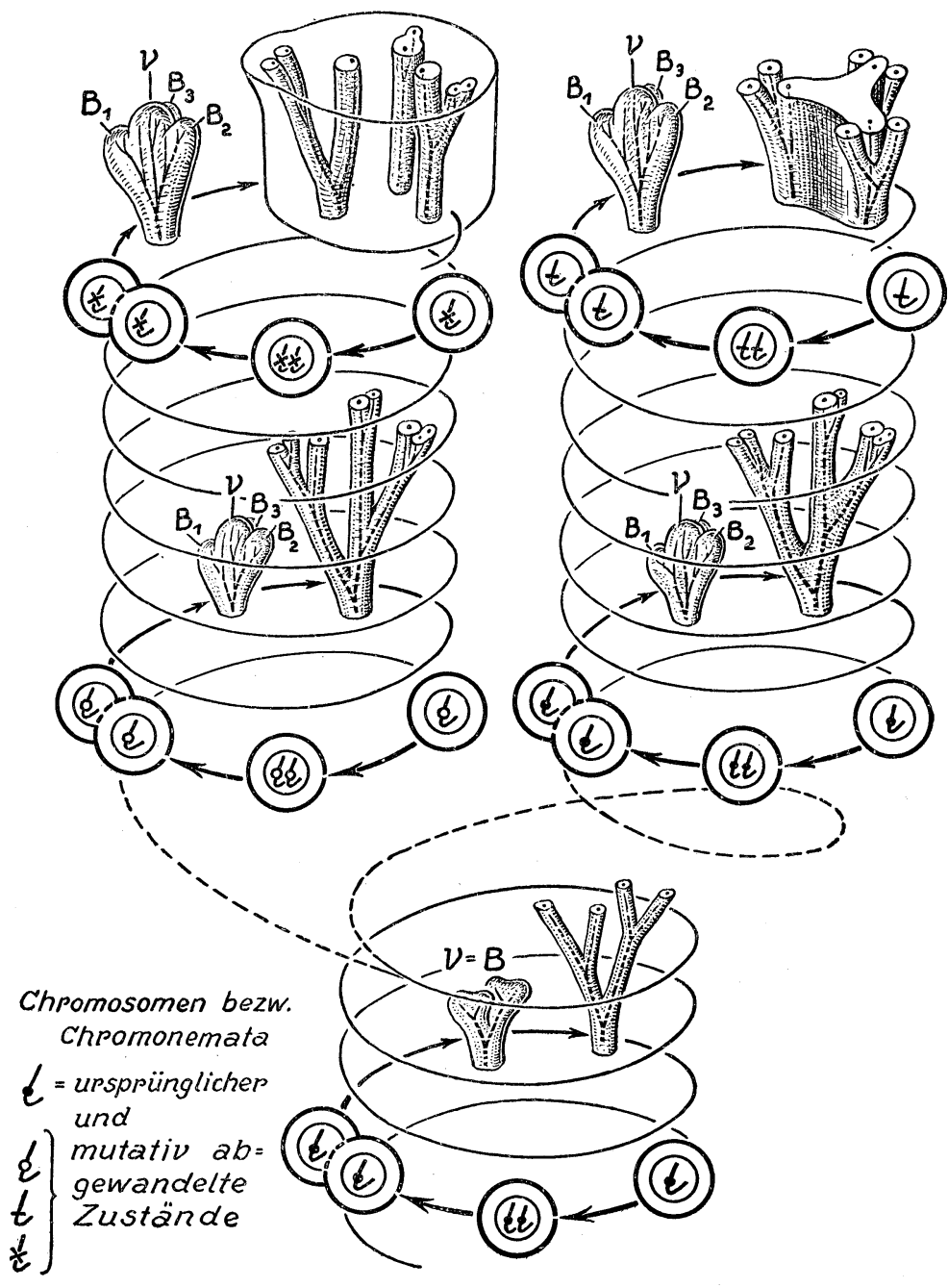

Fig. 1. Hologeny of the stele. process of stele development which is more versatile and, for all, more complicated. In fact this process is what I called a " hologeny" (Fig. 1), namely a continuous series of ontogenies that begins with the ontogeny of the ancestors.

To seize the actual phylogenetic development of the stele we have to be conscious of the hologenetic relation. Moreover, we have to bear in mind: a phylogenetical change starts with changes of the genotype: this genotypic change induces an alteration and wandering of the determinating impulses in

the embryonal tissue; in consequence, the embryonal development shows an altered differentiation with regard to shape, position and sequence of organ formation.

With reference to the stele that means: also the ancestors developed an "initial tissue" (procambium, protophloem and protoxylem) near the growing point. In accordance with the physiological development these initial stages subsequently originated the ontogenetically "complete" stele which is characterized by typical cross sections, as represented in Fig. 4.

In the descendants, under the influence of the changed genotype, the determining factors of the embryonal tissue begin to act in the initial stages, and particularly in the later stages. The growing point is undergoing a kind of new-cast, whereby a "shifting" of the tissue can take place; this process is marked by a changed habitus, by a changed local arrangement, and by a changed timely sequence of the 
"complete" tissue.

\section{The original structure of the stele}

According to prevailing opinion the original type of the stele is the protostele with central protoxylem. This type is represented by the telomes and mesomes of the Rhyniaceae (Rhynia ${ }^{2}$ ) and Horneophyton) and some Primofilices. The protostelic telomes are characterized by a strong radial syrnmetry. The tissues are arranged in layers of concentrical cylinders: The central protoxylem is surrounded by the cylindrical metaxylem (as in Rhynia major and Horneophyton, see Fig. 2), then by a cylinder of phloem (or a precursor of phloem) and finally by a cortical parenchyma and the epidermis.

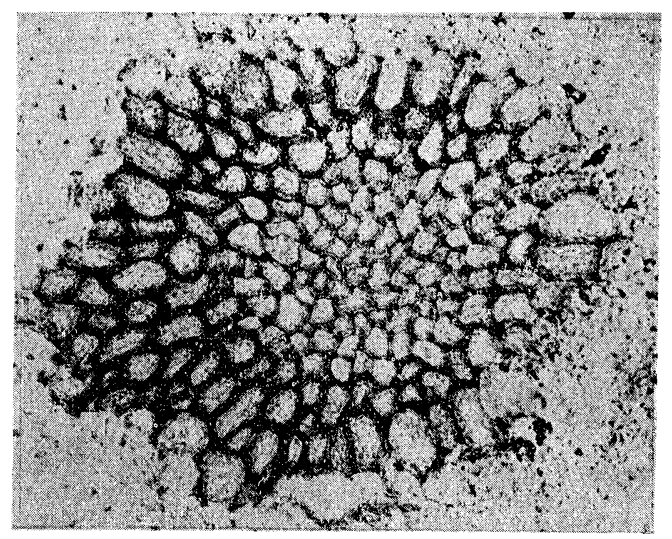

Fig. 2. Protostele of Rhynia major.

Ontogenetically we discern, already in the vicinity of the growing point, the central procambial strand that gives rise to the first permanent tissue: the protoxylem. This arrangement indicates that here, as in later axes, the initial stele acts on the ontogenetically later tissue in the sense of an organizer ("Organisator"). Especially in the formation of the metaxylem and secondary xylem the determining influence of the protoxylem (or its meristematic precursor) is quite obvious.

Apparently this protostelic structure of archae-syntelomes in Psilophyta is the archetype of the different steles. This is to be proved in the same way as for the archae-syntelomes themselves (Fig. 3). Protosteles and archae-syntelomes dominate in the oldest land-plants. The primary protosteles dichotomise like the primary syntelomes.

\section{The initial stage of derivated steles}

The ontogenetically complete steles (Fig. 4) are marked by an extreme difference in appearance, while the initial stages show an astonishing resemblance.

In almost all cases we find a cylinder of strand-initials ("Initialen-Buendelrohr" Fig. 5A and 9B). That means, there appears at the beginning of vascular differentiation a cylinder of strands in the vicinity of the growing point. These strands represent an "open", non-anastomising system, at least in the axes of archaic stems. The same open structure prevails in all primitive organs (as well in leaves as in axes). The initial strands of this cylinder are forked into cauline bundles (" meristeles") and leaf traces (Fig. 9B).

In these initial stages the differences between the various types of the stele are restricted mainly in two features:

1) The number of cauline bundles varies from 3 (e. g. Sphenophyllum) or 4 (Stauropteris) or 5 (Lyginopteris) to more than 100 (Calamites).

2) The leaf traces branch off in different directions (as indicated in Fig. 5A).

2) Rhynia itself is found much later than the other genera, other members of Khyniaceae ex. isted already in the Silurian time. 

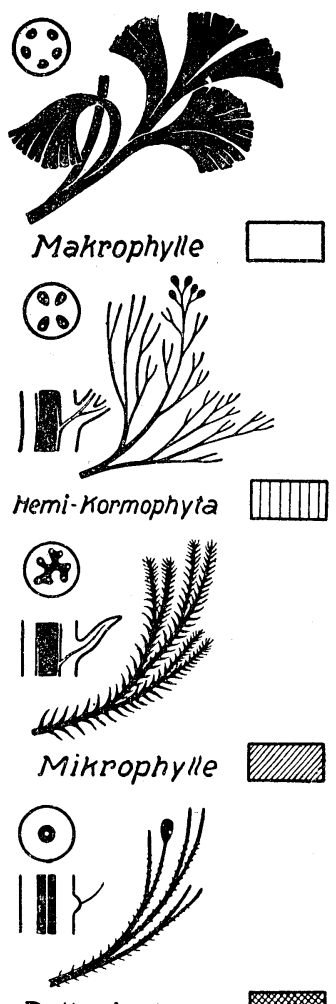

Psilophyton

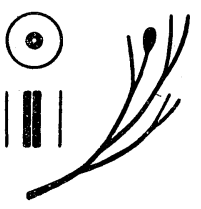

Rhynia

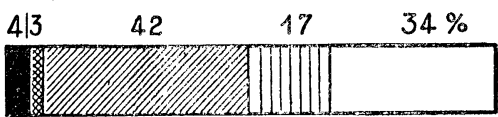

Oberdevon

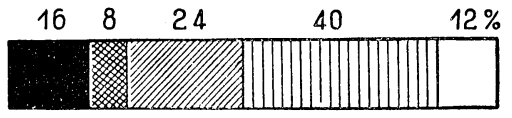

Mitteldevon

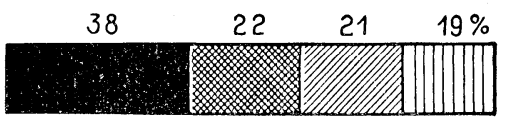

Unterdevon

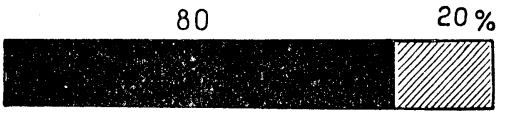

Australisches Silur

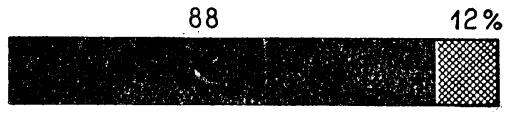

Nordeurop. Silup

Fig. 3. A statistical proof for primitiveness of archaesyntelomes.

On the left: 5 types of oldest land-plants, on the right: their distribution ( $\%$ of species) in the geological time. (See p. 403).

Sphenophyta, results.

We should keep in mind that, from a hologenetic aspect, the first change in this process is marked by the actual shifting of the determinating factors near the growing point.

2) Differentiation between cauline and foliar bundles by overtopping (Fig. 5B). This process corresponds entirely to the external overtopping of the shoot axis over the leaves and is its anatomical consequence. It is not possible to enter into particulars.

\section{The formation of metaxylem and other permanent tissue}

We mentioned already that the formation of metaxylem, as a rule, takes place 
in connection with the protoxylem and apparently under the determining influence of the latter.3) This determining effect is manifested by the generally close relation of tracheidal elements in the metaxylem to the protoxylem, and the same usually applies to the secondary xylem. The different structure of the different steles results from a varying direction in the differentiation of the metaxylem which is demonstrated by some examples in Fig. 7.

In all cases the initial structure of the stele is the same, i.e. the cylinder of strand. initials ("InitialenBündelrohr"), which is represented by the strands of procambium or protoxylem (see Fig. 9 B). After this formation of the cylinder of strand-initials we see in Fig. 7 the following extensions of metaxylem:
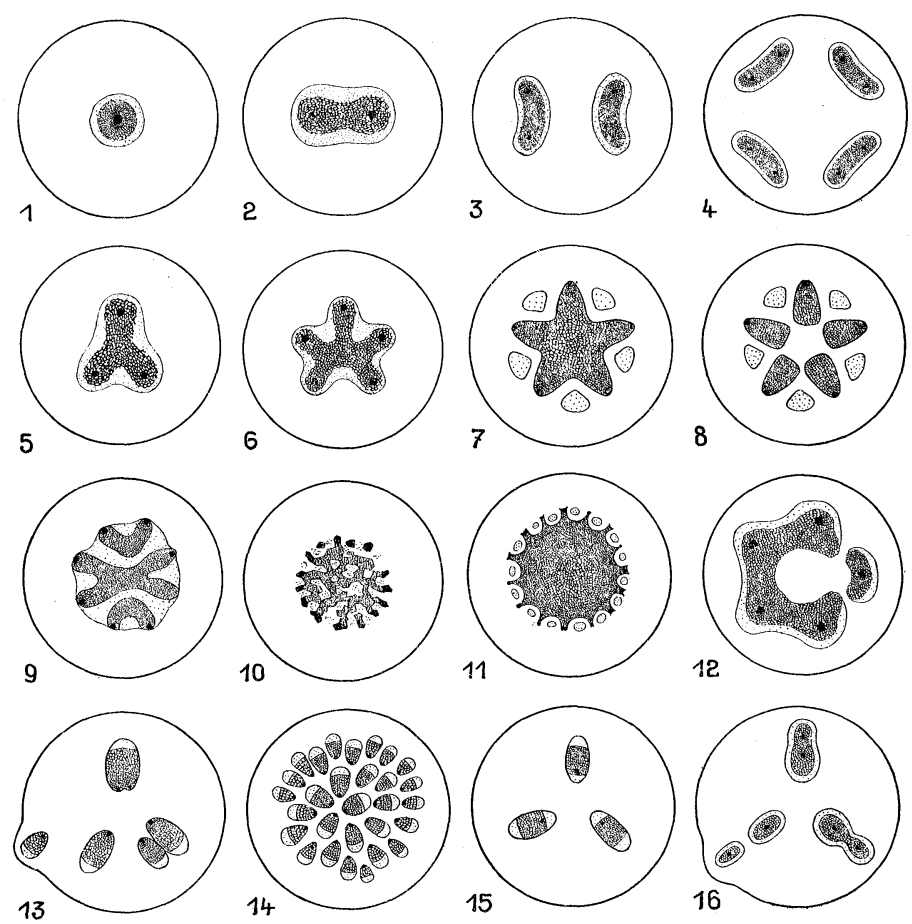

Fig. 4. Survey of stele types.

Light stippling: phloem; darker portions : metaxylem; black points: protoxylem.
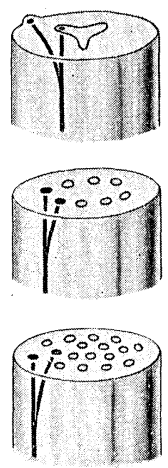

A
$\mathrm{B}$

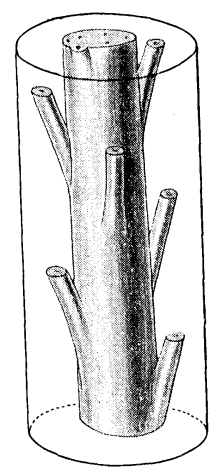

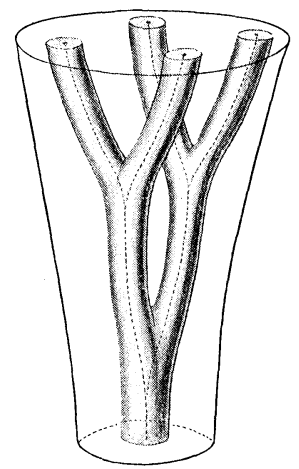

$\mathrm{C}$
Fig. 5. A) Scheme of the cylinder of "strand-initials."

B) Overtopping and C) syngenesis of the stele.

in the protostele and polystele a radial extension of metaxylem (in the protostele the extension of metaxylem begins with one and in the polystele with several strand-initials);

in the eustele a centrifugal extension of metaxylem;

in the actinostele a centripetal extension of metaxylem;

in the siphonostele a tangential extension of metaxylem. Apparently there are determining factors which direct the growth of metaxylem in these directions.

3) For our question it is without relevance, if this determining impulse proceeds from the promtoxylem itself or, what is more probable, from its embryonal pre-stages. 


\section{Some characteristic instances}

Asteroxylon Mackiei, M. Devon. (Fig 8).

The adult shoot has an actinostele with " mesarch" primary xylem in the "branches".
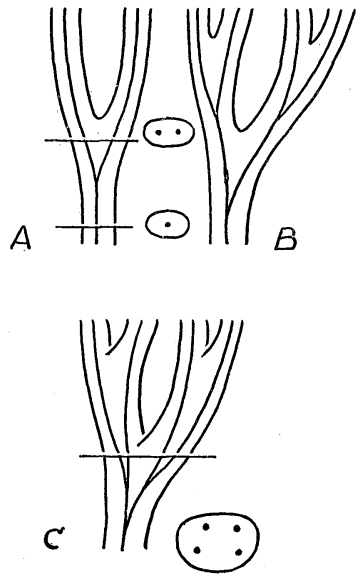

Fig. 6. $\mathrm{A}-\mathrm{C}$.

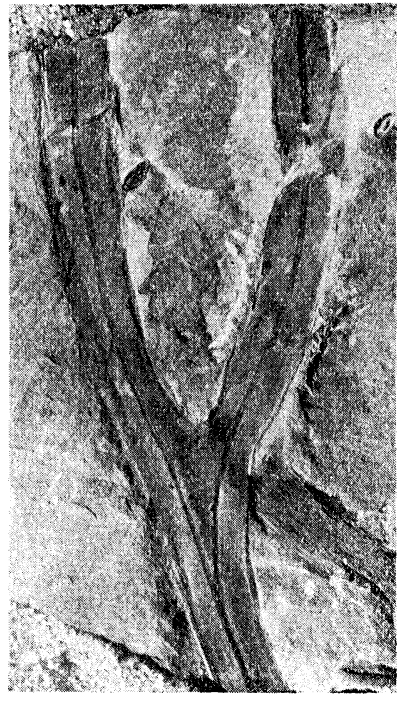

Fig. 6. D.

Beginning of syngenesis in Taeniocrada Langi. (See p. 404).

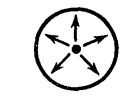

Protostele

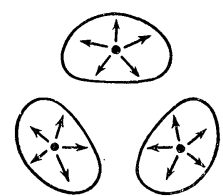

Polystele

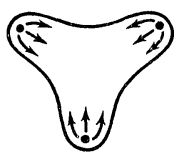

Actinostele

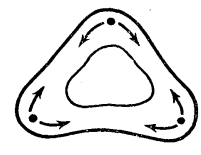

Siphonostele

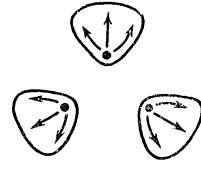

Eustele

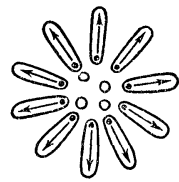

Pietzschia

Fig. 7. Directions of metaxylem extension. (See p. 405).

This implies an initially more or less centrifugal differentiation which is soon followed by a strictly centripetal extension; hence the xylem "branches" close up in the center of the shoot axis.

From the "branches" the leaf traces are forked off centrifugally. They are constructed in principle on the same model as the earlier initial strands of the axis (mesarch protostele as in Fig. $8 \mathrm{~B}$ ).

Three ontogenetical stages can be observed immediately:

a) The procambial stage in the bud of Asteroxylon (Fig. 8A). Here we have a characteristic procambial cylinder of initial strands, whose general structure corresponds to Fig. 1, middle. The cylinder of initial strands consists in shoot-buds with 4 to 6 cauline strands, well recognizable as dark, stretched cells filled with plasma. By one or two

dichotomous furcations they detach procambial forerunners of leaf traces.

b) The stage of the first metaxylem is represented in principle by Fig. 1, upper left. As in the protostele, the metaxylem is formed radially around the protoxylem, i.e. in "mesarch" position to the latter.

c) This protostelic differentiation is stopped soon. In the cauline bundles the metaxylems (wide tracheids) grow only centripetally, conforming with the actinostele; accordingly the "branches" join in the center. The leaf traces remain in the earlier stage $b$.

The steles of the later Lycophyta, differ from Asteroxylon by an "exarch" posi- 
tion of the protoxylem. That means, the determining effect of the protoxylem acts only in centripetal or tangential direction, respectively. In some Sigillaria (for instance Sigillaria ele. gans Sternberg) the centripetal determination of the metaxylem does not reach the center of the axis; hence we find a "pith". This type of the stele is called "siphonostele", particularly since the metaxylem formation goes, to a large extent, also in tan. gential direction. Generally speaking, the wood creates the impression of a cylinder.

Lyginopteris oldhamia (Fig. 9).

In this upper Devonian Pteridophyta equally three ontogenetical stages are to be discerned:
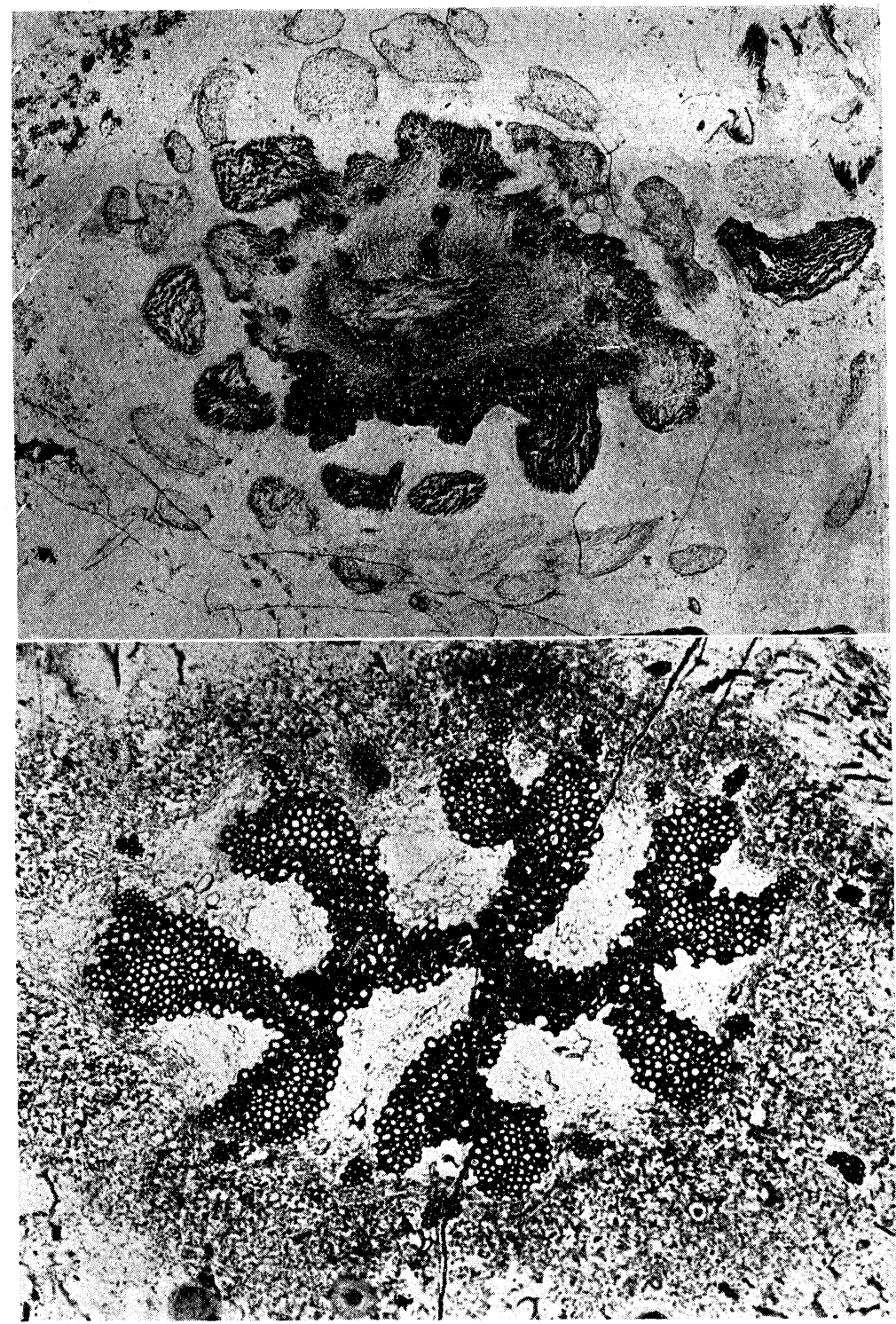

Fig. 8. A-B. Asteroxylon. (See p. 406).

a) Like in Asteroxylon, the procambial stage shows, in principle a distinct cylinder of strand-initials. By tangential furcation the five cauline bundles detach the foliar bundles, similar to the $2 / 5$ position of the leaves. The latter divides further in a characteristic way, namely in the same internode in which the cauline bundles go on to bifurcate. Thence the whole stele reveals evidently the original dichotomous organization of the protostele in Psilophyta (See Fig. 9 B).

b) The metaxlyem stage shows a radial structure and corresponds so far still to the Psilophyta: we can speak of " mesarch" meristeles or bundles, respectively. True, the metaxylem differentiating effect of the protoxylem goes somewhat more in centripetal than in centrifugal direction. 


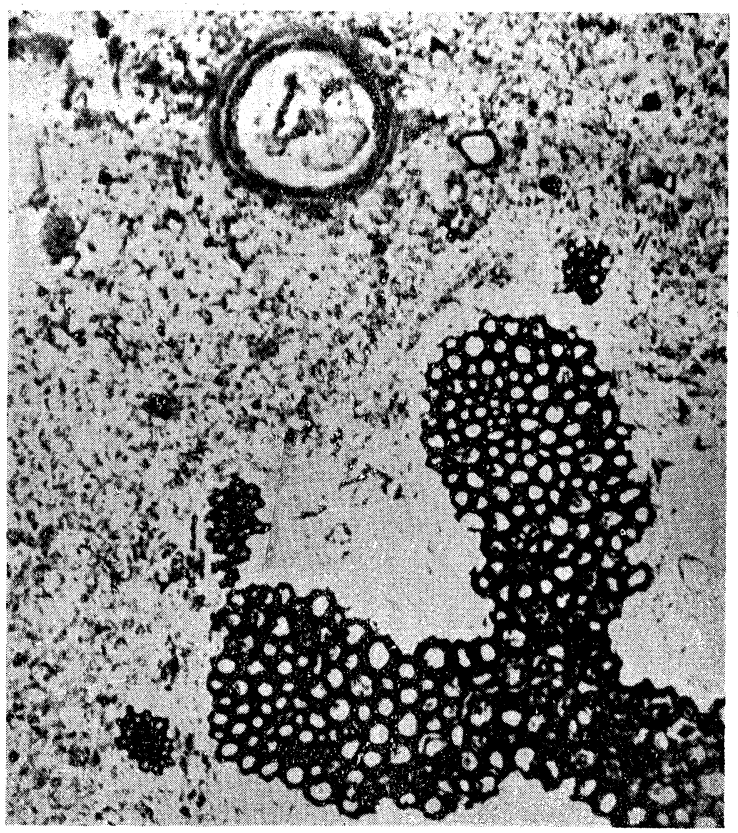

Fig. 8. C. Asteroxylon, part of Fig. 8.B. (See p.406).

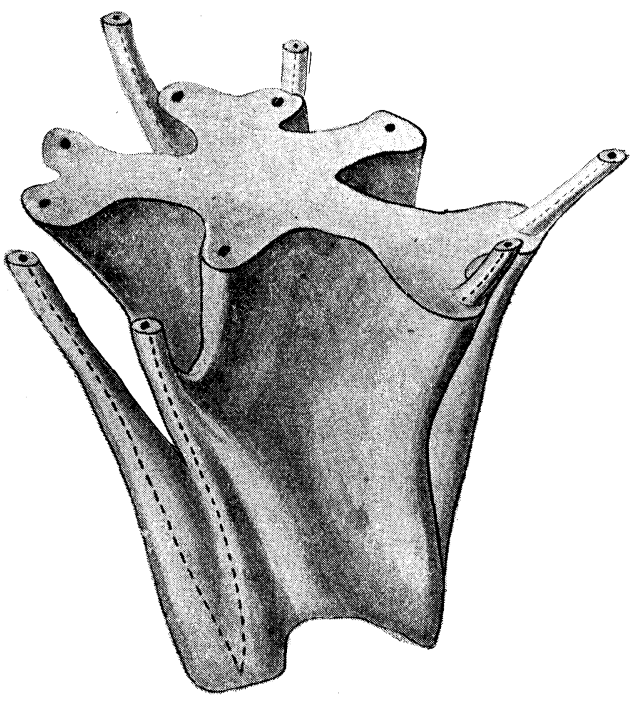

Fig. 8. D. Asteroxylon, wood.

c) In the stage of later wood formation, mainly that of secondary wood, a nearly exclusive centrifugal differentiation takes place. Though, besides, we know some forms of Lyginopteris which, at least to some extent, have a radial differentiation within the secondary wood (similar to Medullosa).

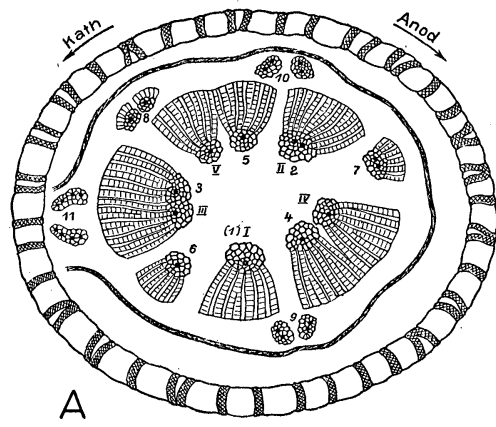

Fig. 9. Lyginopteris. (See p. 407;

Other Pteridophyta. A centripetal differentiation of the metaxylem is rather conspicuous in some early Pterophyta. The typical actinostele 4 occurs in some Primofilices (for instance Stauropteris) though, in general, the axes of Pterophyta are characterized by polysteles, eusteles and siphonosteles; that means, the metaxylem is differentiated in different directions as described above (Fig. 7).

\section{Medullation}

In the earlier stelar theory (Fig. $10 \mathrm{~A}$ and $\mathrm{B}$ ) a conception developed deviating from the notion demonstrated above. According to that theory the medullation-

4) Thence the actinostele is the dominating type of the archae-stele; it is present in ancient Sphenophyta like Sphenophyllum, and we ascertained previously a fairly conforming type for Lyginopteris. 
that is the formation of parenchymatous tissue within the protostelic center of the axis - is assumed to take place by "transformation" or "sinking in" of parenchyma into the axial center. These conceptions do not correspond to fossil findings nor to the ontogenetical rrocesses of the ancestors. The (firstly protostelic) strands are always formed isolated, though they may merge in an actinostele by profuse development of centripetal metaxylem; this is the case mainly in archaic axes. The siphonostele, too,
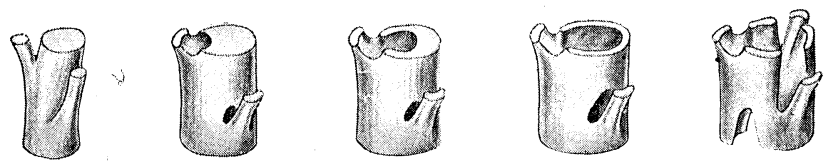

A. "Sinking in" of parenchyma (JEFFREY)
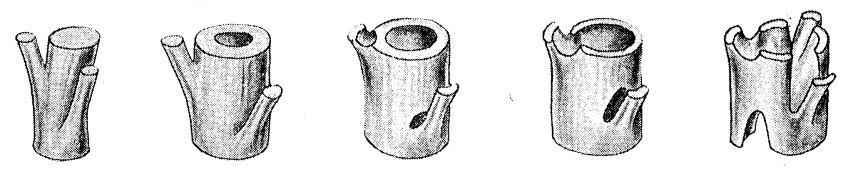

B. "Transformation" to medulla [KIDSTON \& GWYNNEVAUGHAN]
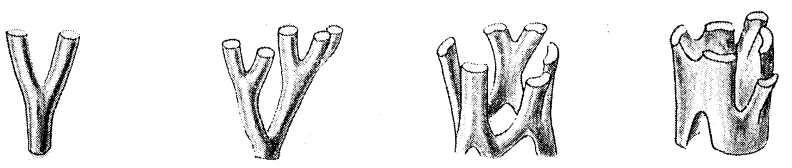

C. "Basipetal shifting" of stele-ramification [ZIMMERMANN`

Fig. 10. Theories of medullation.

arises from subsequent fusion of tangential metaxylem within a cylinder of initial strands. Within the Pterophyta the Permian Osmundales seems to be the first to present the siphonostele. (They show a typical cylinder of initial strands that corresponds to the position of the protoxylem strands). Recent Osmundales possess isolated strands. That means, the determining power of protoxylem here is limited to isolated strands.

\section{Zusammenfassung}

1. Die Ahnengestalt der Stele, wie sie bei den ältesten Landpflanzen (zum Beispiel Rhyniaceae) ausgebildet ist, war eine Protostele mit centralem Protoxylem.

2. Bei ihrer phylogenetischen Abwandlung bildet sich in der Ontogenie in allen Stelen zunächst das “Initialen-Bündelrohr”, ein Zylinder aus “kaulinaren" Prokambium - beziehungsweise Protoxylem - Strängen, von denen ähnlich gebaute Blattspuren ausgehen.

3. Die verschiedenen Typen der Stelen ergeben sich dann durch wechselnde Differenzierung der Folgegewebe (Metaxylem, Sekundärholz und so fort). Diese Folgegewebe werden offensichtlich ausstrahlend vom Protoxylem aus determiniert. Das verschiedenartige Aussehen der Stelen ergibt sich dann vor allem durch die wechselnde Richtung, in der die determinierende Wirkung sich zeigt.

For detailed references (also for Fig. 1-9) see

Zimmermann, W. 1954. Ueber die mikrophyllen "Psilophyten", ihre Entstehung und Bedeutung für die Stammesgeschichte. Paläont. Z. 28: 56.

" 1954. Das Homologieproblem, erläutert am Beispiel der Stelärtheorie. Ber. d. Dtsch. Bot. Ges., 67: 312

"1955. Wie die Pflanzen an Land gegangen sind. Kosmos, 10: 461.

" Phylogenie der Pflanzen. Jena 1930, 2. Auflage. In press. 